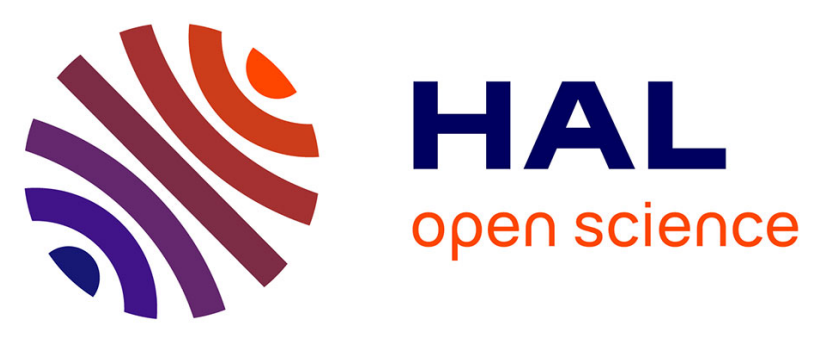

\title{
Cross-resistance to moxidectin and ivermectin on a meat sheep farm in France
}

C. Paraud, T. Marcotty, Anne Lespine, Jean-Francois Sutra, I. Pors, I. Devos

\section{To cite this version:}

C. Paraud, T. Marcotty, Anne Lespine, Jean-Francois Sutra, I. Pors, et al.. Cross-resistance to moxidectin and ivermectin on a meat sheep farm in France. Veterinary Parasitology, 2016, 226, pp.88-92. 10.1016/j.vetpar.2016.06.033 . hal-02633599

\section{HAL Id: hal-02633599 \\ https://hal.inrae.fr/hal-02633599}

Submitted on 27 May 2020

HAL is a multi-disciplinary open access archive for the deposit and dissemination of scientific research documents, whether they are published or not. The documents may come from teaching and research institutions in France or abroad, or from public or private research centers.
L'archive ouverte pluridisciplinaire HAL, est destinée au dépôt et à la diffusion de documents scientifiques de niveau recherche, publiés ou non, émanant des établissements d'enseignement et de recherche français ou étrangers, des laboratoires publics ou privés.

\section{(ㅇ)(1) $\$$}

Distributed under a Creative Commons Attribution - NonCommercial - NoDerivatives| 4.0 


\section{Accepted Manuscript}

Title: Cross-resistance to moxidectin and ivermectin on a meat sheep farm in France

Author: C. Paraud T. Marcotty A. Lespine J.F. Sutra I. Pors I. Devos

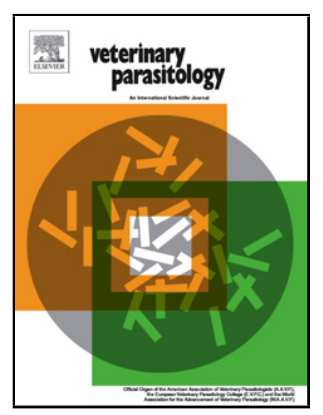

PII: S0304-4017(16)30252-7

DOI: http://dx.doi.org/doi:10.1016/j.vetpar.2016.06.033

Reference: VETPAR 8066

To appear in: $\quad$ Veterinary Parasitology

Received date: $\quad$ 5-2-2016

Revised date: $\quad$ 18-6-2016

Accepted date: $\quad$ 24-6-2016

Please cite this article as: Paraud, C., Marcotty, T., Lespine, A., Sutra, J.F., Pors, I., Devos, I., Cross-resistance to moxidectin and ivermectin on a meat sheep farm in France.Veterinary Parasitology http://dx.doi.org/10.1016/j.vetpar.2016.06.033

This is a PDF file of an unedited manuscript that has been accepted for publication. As a service to our customers we are providing this early version of the manuscript. The manuscript will undergo copyediting, typesetting, and review of the resulting proof before it is published in its final form. Please note that during the production process errors may be discovered which could affect the content, and all legal disclaimers that apply to the journal pertain. 


\section{Highlights}

- The first description of double resistance of Teladorsagia circumcincta to moxidectin and ivermectin in sheep in France is reported.

- $\quad$ Resistance is assessed through the association of classical methods of detection of resistance (FECRT and efficacy test).

- Pharmacokinetics of moxidectin and ivermectin were used to confirm that parasites were exposed to anthelmintic concentrations usually lethal for them. 


\title{
Short communication
}

\section{Cross-resistance to moxidectin and ivermectin on a meat sheep farm in France}

\author{
C. Parauda, T. Marcottyb, A. Lespinec, J.F. Sutrac, I. Pors ${ }^{\mathrm{a}}$, I. Devos ${ }^{\mathrm{d}}$
}

a ANSES Niort laboratory, 60 rue de Pied de Fond, CS 28440, 79024 Niort cedex, France

b VERDI R\&D, Sadzot 11, 6997 Erezée, Belgium

c Institut National de la Recherche Agronomique, UMR 1331 INRA/INP, Toxalim Research

Centre in Food Toxicology, 180 chemin de Tournefeuille - BP 93173, F-31027 Toulouse Cedex 3,

France; Université de Toulouse, INP, UMR 1331, Toxalim, F- 31000 Toulouse, France

d Clinique Vétérinaire des Montagnes du Matin, route de Tarare, 42360 Panissières, France

Corresponding author: Carine Paraud

Tel: +33549796128

Fax: +33 549794219

e-mail: carine.paraud@anses.fr

Submitted to Veterinary Parasitology, second version 


\section{Abstract}

Resistance to ivermectin and moxidectin was explored by a faecal egg count reduction test in two sheep flocks with suspected anthelmintic resistance. The FECRT confirmed one suspicion, with a mean percentage of reduction in egg excretion within the treated groups of $0 \%$ for ivermectin (CI 95\%:-228 - 58) and 13\% for moxidectin (CI 95\%:-152 70). This was further explored by a controlled efficacy test. An experimental infection of 18 naïve lambs was set up using infective larvae isolated from this flock (5000 L3/lamb). Compared to the control group, abomasal worm burdens (Teladorsagia circumcincta) were reduced by 90\% [CI 95\%: 81.5-94.8] and 85\% [CI 95\%: 72.4-92.2] after ivermectin $(\mathrm{p}<0.05)$ and moxidectin $(\mathrm{p}<0.05)$ treatment respectively. Again, compared to the control group, there was a reduction for intestinal strongyles (Trichostrongylus colubriformis) of 100\% and 99\% [CI 95\%: 97.5-99.7] for ivermectin and moxidectin respectively. No difference was found between the efficacy of moxidectin and ivermectin. Pharmacokinetic values indicated that the strongyles were submitted to anthelmintic concentrations usually lethal to them. This trial demonstrated the first multiple resistance of ovine strongyles in France.

Keywords: sheep; FECRT; efficacy test; pharmacokinetic parameters; moxidectin; ivermectin; resistance. 


\section{Introduction}

Anthelmintic resistance in small ruminant strongyles has been known for several years. A recent review reported that anthelmintic resistance is widespread among European farmed ruminants (Rose et al., 2015). The three main species infecting sheep (Haemonchus contortus, Teladorsagia circumcincta and Trichostrongylus colubriformis) and all the anthelmintic families are concerned.

In this study, we explored two field suspicions of resistance to ivermectin and moxidectin by a faecal egg count reduction test (FECRT), which is the standard field test for the diagnosis of anthelmintic resistance in small ruminants (Coles et al., 2006). In one case, this was followed by a controlled efficacy test comprising pharmacokinetic analysis of the two anthelmintics .

\section{Materials and methods}

\subsection{FECRT}

The first flock was a meat sheep flock situated in the Loire département (a département being a French administrative and territorial unit) comprising 420 Ile de France ewes. The ewes graze from April to November with a density of ten ewes/ha and a small degree of pasture rotation. They are treated by oral moxidectin (MOX) in June and November and with injectable MOX or ivermectin (IVM) when they come back from summer pastures. Lambs are treated with oral MOX every 35 days. Rams are not treated at the time of integration in the flock. 
The second meat sheep flock was situated in the Allier department and comprised 700 Ile de France ewes. The ewes graze all year round, without any pasture rotation. They were treated four times a year with levamisole and oxfendazole alternately until 2003 then levamisole-IVM from 2003 to 2006 and from then onwards with levamisole-MOX alternately. Lambs were treated at 30 days old with benzimidazoles and at 60 days old with levamisole until 2003 then with MOX until now. Since 2009, the rams have been given MOX when integrated in the flock.

In each flock, FECRT was conducted according to the recommendations of the World Association for the Advancement of Veterinary Parasitology (WAAVP) (Coles et al., 2006). Three groups of 15 lambs per flock were randomly constituted:

- Control group: 15 lambs were left untreated,

- IVM group: 15 lambs were given $0.2 \mathrm{mg} / \mathrm{kg}$ bodyweight (BW) of IVM orally (Oramec ${ }^{\circledR}$, Mérial, France),

- MOX group: 15 lambs were given $0.2 \mathrm{mg} / \mathrm{kg}$ BW of MOX orally (Cydectine ${ }^{\circledR}$, Zoetis, France).

All the lambs were weighed and treated with the exact dose. Individual faecal samples were collected before and 16 days after treatment.

Individual faecal egg counts were completed using a modified McMaster technique (flotation solution: magnesium sulphate $(d=1.25)$, sensitivity: 50 eggs per gram of faeces (epg)) (Raynaud, 1970). The remaining faeces were pooled to perform group coprocultures performed separately for control and treated groups. Infective larvae were harvested by the Baermann technique and identified to genera level (MAFF, 1986). 
For each group and time, mean epg was calculated using a binomial negative regression (epg being the response variable, and group and date the explanatory variables).

The percentage of reduction was estimated using the estimated means in the Presidente formula (Presidente, 1985): FECR $=100 \times(1-[\mathrm{T} 2 / \mathrm{T} 1][\mathrm{C} 1 / \mathrm{C} 2])$ where $\mathrm{T} 1$ and $\mathrm{T} 2$ were pre- and post-treatment geometric means of the epg in treated groups respectively, and $\mathrm{C} 1$ and $\mathrm{C} 2$ were pre- and post-treatment geometric means of the epg in control groups respectively.

Confidence intervals were calculated using a non-linear combination of estimators in Stata (StataCorp).

Results were interpreted according to WAAVP guidelines (Coles et al., 1992).

\subsection{Controlled efficacy test}

In the event of a suspicion of resistance following FECRT, a controlled efficacy test was performed.

Eighteen two-month-old naïve lambs which had never grazed were bought from a commercial flock. Infective larvae were obtained from bulk coprocultures from the flock in which resistance was suspected and each lamb was infected with 5000 L3.

When all the lambs were excreting eggs (35 days post-infection), they were divided up into three groups of six, so that mean egg excretion and mean weights were identical:

- Control group: six lambs were left untreated,

- $\quad$ IVM group: six lambs were given $0.2 \mathrm{mg} / \mathrm{kg}$ BW of IVM orally (Oramec ${ }^{\circledR}$ )

- MOX group: six lambs were given $0.2 \mathrm{mg} / \mathrm{kg}$ BW of MOX orally (Cydectine ${ }^{\circledR}$ ). 
The pharmacokinetics of IVM and MOX were determined: the plasma concentration of IVM and MOX was measured before administration of IVM or MOX and 1, 2, 4, 7 and 8 days post-administration by high-performance liquid chromatography (HPLC) using a previously described method (Lespine et al., 2004).

All the lambs were euthanised ten days after treatment and examined post-mortem. The abomasum and small intestines (the first three metres) were processed as described by MAFF (1986). Worm counts were conducted on aliquots of one tenth of the washing volume of the contents $(500 \mathrm{ml})$. Worms present in the large intestines were sampled directly during post-mortem examination. Species were identified by examining 30 male worms, if available, from each organ.

The trials were carried out in compliance with animal welfare requirements and did not cause any pain according to French regulations on experiment ethics.

Worm burdens in the treated and untreated control group were compared using a Mann-Whitney test, with significance accepted at $\mathrm{p}<0.05$.

Data were analysed using a negative binomial regression. The efficacy of treatment was calculated for each organ and for the whole digestive tract and determined using the formula $([\mathrm{C}-\mathrm{T}] / \mathrm{C}) \times 100$, where $\mathrm{C}$ is the mean adult worm count for the untreated control group and $\mathrm{T}$ is the mean adult worm count for each of the treated groups as described by Mejía et al. (2003). The confidence intervals for adult reduction were calculated by non-linear combination of the negative binomial regression estimates. Pharmacokinetic parameters of IVM and MOX were compared using a Student test, with significance accepted at $\mathrm{p}<0.05$. 


\section{Results}

\subsection{FECRT}

\subsubsection{Flock 1}

The trial took place in June 2013. The lambs were one year old, had been at grass the previous autumn, were naturally infected with nematodes and had a mean weight of 64 $\mathrm{kg}$.

In the control group, the mean egg excretion of gastro-intestinal strongyles was 350 epg at J0 and 118 epg at J16 (Table 1). The mean percentage of the reduction in egg excretion in the treated groups compared to the control group was $0 \%$ for IVM (CI 95\%:228 - 58) and 13\% for MOX (CI 95\%:-152 - 70) (Table 1).

Coprocultures from the control group showed the presence of larvae mainly from the Teladorsagia/Trichostrongylus genera, followed by larvae from the Oesophagostomum/Chabertia genera. After treatment by IVM or MOX, only Teladorsagia/Trichostrongylus larvae were identified.

According to WAAVP recommendations, the FECRT indicated the presence of IVM and MOX resistance in the flock's strongyle population.

\subsubsection{Flock 2}

This trial took place in September 2013. The lambs were six months old, had been grazing since birth, were naturally infected with nematodes and had a mean weight of $44.7 \mathrm{~kg}$. 
In the control group, the mean egg excretion of gastro-intestinal strongyles was 213 epg at J0 and 313 epg at J16 (Table 1). The mean percentage of the reduction in egg excretion in the treated group compared to the control group was $96 \%$ for IVM (CI 95\%: 85 - 99) and 98\% for MOX (CI 95\%: 86 - 100) (Table 1).

Coprocultures from the control group showed the presence of larvae mainly from the Teladorsagia/Trichostrongylus genera and secondarily the Oesophagostomum/Chabertia genera. After treatment, infective larvae were only obtained in the IVM group and were identified as Teladorsagia/Trichostrongylus larvae.

According to WAAVP recommendations, the FECRT indicated only a reduced efficacy of IVM and MOX in this flock's strongyle population.

\subsection{Controlled efficacy test with the infective larvae from flock 1}

All the lambs were free from infection before experimental infection. An anthelmintic treatment was administered 35 days post-infection, when all the lambs were excreting strongyle eggs.

Before anthelmintic treatment, mean egg excretion varied from 383 to 400 epg per group and mean live weight varied between 23 and $25 \mathrm{~kg}$ per group.

The plasma disposition kinetics of IVM and MOX are shown in Figure 1 and Table 2. For IVM, the mean observed $\mathrm{C}_{\max }$ was $15.27 \mathrm{ng} / \mathrm{ml}$, obtained at 0.5 days post-administration. For MOX, $\mathrm{C}_{\max }$ was $9.64 \mathrm{ng} / \mathrm{ml}$, also obtained 0.5 days post-administration. $\mathrm{T}_{\max }$ was at 0.5 days for both IVM and MOX. Both drugs were detected at significant levels $(>1$ $\mathrm{ng} / \mathrm{ml}$ ) until the fourth day post-treatment. These data show that IVM or MOX were 
present in the plasma of the host after oral treatment at levels and during a period of time which were expected in lambs after a therapeutic oral drench.

At slaughter, worm burdens in the control group varied between 220 and 670 worms in the abomasum (T. circumcincta), between 770 and 1,430 worms in the small intestine (T. colubriformis) and between 12 and 110 adults/caecum for 0 . venulosum (Table 3 ). At slaughter, ten days after anthelmintic treatment, there were only T. circumcincta adults present in the abomasum of the IVM group (mean worm burden: 57 adults/abomasum) (Table 3). In the MOX group, T. circumcincta adults were present in the abomasum (mean worm burden: 85 adults/abomasum) but there were also small numbers of T. colubriformis in the small intestines of three lambs $(10,10$ and 30 worms). For both anthelmintics and all the strongyle species, the mean number of adult worms was significantly lower in the treated groups than in the control group (Table 3).

The percentage of reduction in T. circumcincta was 90\% for IVM (CI 95\%: 82 - 95) and $85 \%$ (CI 95\%: 72 - 92) for MOX (Table 3). No significant difference in the efficacy of IVM and MOX against T. circumcincta was observed $(\mathrm{p}=0.2)$. Regarding efficacy against $\mathrm{T}$. colubriformis, IVM was $100 \%$ effective and MOX reduced worm counts by more than 99\% (CI 95\%: 97 - 100).

Taken together, the drug concentration profile in the lamb plasma and efficacy results clearly reveal a failure in drug efficacy rather than a dosing error or incorrect drug absorption. This confirms that the T. circumcincta isolate from flock 1 is resistant to IVM and MOX. 


\section{Discussion}

For the first time, we report a macrocyclic lactone (ML) resistance in sheep in France, with an isolate of Teladorsagia circumcincta resistant to both MOX and IVM. Resistance of T. circumcincta to ML in sheep has been previously described in several European countries for several years (Rose et al., 2015). In France, previous random studies have failed to find IVM and/or MOX resistance in sheep (Doré et al., 2010; Geurden et al., 2014). The first hypothesis to explain this absence is that resistance is a recent phenomenon in French flocks. This could be explained by different management and/or treatment practices in France compared to other European countries. Charlier et al. (2010) reported that treatment practices for dairy calves differ considerably in nearby countries like Belgium, Germany and Sweden. This hypothesis does not appear very credible. The second hypothesis considers that the studies set up to detect resistance failed to detect developing resistance because of their characteristics. For example, Doré et al. (2010) conducted FECRTs in only five flocks, with 12 animals per treated group and one control group also of 12 animals, and a counting method sensitivity of 50 epg: all these factors prevented the authors from drawing clear conclusions on the resistance status of the flocks, apart from cases of marked resistance (Levecke et al., 2012).

The controlled efficacy test is still considered the gold standard, despite its cost. Some discrepancies between FECRTs with naturally grazing animals showing resistance and experimental infections invalidating these suspicions have been previously reported (Paraud et al., 2013; Areskog et al., 2014), indicating that the FECRT alone cannot be reliably used to detect resistance.

A comparison between the current results of the FECRT and experimental infection reveals that a higher reduction is obtained for experimental infection (determined in 
adults) than for natural infection (based on egg counts). Such discrepancies were also reported by Mejía et al. (2003) in cattle. The first hypothesis to explain this difference is that the proportion of strongyle species involved in the two different steps may play a role in the evaluation of efficacy. The FECRT was conducted in late spring, while the mass coproculture for experimental infection was set up in late autumn. It was previously reported both in sheep and goats that a change in the dominant strongyle species occurs during the grazing season, T. circumcincta being dominant in spring, and T. colubriformis in autumn (Gruner et al., 1980). It may therefore be hypothesised that the resistant $\mathrm{T}$. circumcincta were less present during the experimental infection, which explains the higher reduction percentage observed in this part of the study. The second hypothesis is that side effects accentuated the low efficacy of treatment in the field trial compared to the experimental trial. In both the farm and experimental trials, the same molecules and same medicinal products were given to lambs by the same route at the same dose. The levels of egg excretion were similar, but the lambs were different. For the farm trial, older lambs (one year old) which had previously been at grass were involved during the grazing season, while for the experimental infection, we used very young lambs (two months old) which were reared indoors and totally naïve to parasitism. The bodyweight, body condition and amount and type of nutrition were therefore different, and these factors are known to influence IVM plasma concentration (González Canga et al., 2009).

For the experimental infection, the parasitology data were consolidated by measuring the drug concentration in the host plasma after drug treatment. Plasma concentration is closely related to IVM concentration in target tissues such as the abomasum (Lifschitz et al., 2000). The plasma disposition kinetics are similar to those previously reported in infected lambs (Lloberas et al., 2013). These pharmacokinetic data demonstrated that 
parasites were exposed to concentrations of anthelmintic usually lethal for them, and confirmed the presence of resistant worms.

In flock 1, both IVM and MOX are used regularly, a practice that can lead to selection for resistance, as demonstrated in experimental conditions by Van Zeveren et al. (2007).

In flock 2, no clear conclusion could be drawn from FECRT results and there was unfortunately no controlled efficacy test for confirmation purposes. Levecke et al. (2012) previously stated that the diagnostic value of FECRT for detecting small reductions in efficacy is limited. In our situation (15 animals per group with a detection limit between 15 and 50 epg and pre-treatment excretion between 50 and $1000 \mathrm{epg}$ ), for an anthelmintic with a normal efficacy higher than 95\%, the latter authors estimated that for a reduction between $87.5 \%$ and $97.5 \%$, the true drug efficacy cannot be accurately defined.

The difference in resistance between the two flocks can be explained by risk factors present in flock 1 and not in flock 2: exclusive use of ML treatments for both ewes and lambs, a treatment interval in lambs corresponding closely to the prepatent period, no treatment before the integration of rams and common grazing with other flocks during the summer.

This demonstration of cross-resistance to ivermectin and moxidectin argues in favour of promoting sustainable ways of using anthelmintics in French sheep flocks. The management principles of the SCOPS implemented in the UK would be of interest for implementation in France, i.e. to administer treatment by dosing according to the heaviest animal in the group, calibrate the dosing gun for each treatment, carry out quarantine drenching and selective treatments, avoid drenching lambs immediately 
prior to moving them to clean pastures, and finally to use or avoid treating ewes around the lambing period (Learmount et al., 2015).

\section{Acknowledgements}

The authors are grateful to Dr MADET who took the samples in one flock.

They would also like to thank the Région Aquitaine Limousin Poitou-Charentes and SNGTV (Société Nationale des Groupements Techniques Vétérinaires, 5 rue Moufle, 75011 PARIS) for their financial support.

\section{References}

Areskog, M., Sollenberg, S., Engström, A., von Samson-Himmelstjerna, G. Höglund, J., 2014. A controlled study on gastrointestinal nematodes from two Swedish cattle farms showing field evidence of ivermectin resistance. Parasit. Vectors 7, 13.

Charlier, J., Demeler, J., Höglund, J., von Samson-Himmelstjerna, G., Dorny, P., Vercruysse, J., 2010. Ostertagia ostertagi in first-season grazing cattle in Belgium, Germany and Sweden: General levels of infection and related management practices. Vet. Parasitol. 171, 91-98.

Coles, G.C., Bauer, C., Borgsteede, F.H.M., Geerts, S., Klei, T.R., Taylor, M.A., Waller, P.J., 1992. World Association for the Advancement of Veterinary Parasitology (W.A.A.V.P.) methods for the detection of anthelmintic resistance in nematodes of veterinary importance. Vet. Parasitol. 44, 35-44.

Coles, G.C., Jackson, F., Pomroy, W.E., Prichard, R.K., von Samson-Himmelstjerna, G., Silvestre, A., Taylor, M.A., Vercruysse, J., 2006. The detection of anthelmintic resistance in nematodes of veterinary importance. Vet. Parasitol. 136, 162-185. 
Doré, C., Paraud, C., Vermesse, R., Tanguy, I., Le Dréan, E., Chartier, C., 2013. Résistance aux anthelminthiques chez les ovins. Le Point Vétérinaire 308.

Geurden, T., Hoste, H., Jacquiet, P., Traversa, D., Sotiraki, S., Frangipane di Regalbono, A., Tzanidakis, N., Kostopoulou, D., Gaillac, C., Privat, S., Giangaspero, A., Zanardello, C., Noé, L., Vanimisetti, B., Bartram, D., 2014. Anthelmintic resistance and multidrug resistance in sheep gastro-intestinal nematodes in France, Greece and Italy. Vet. Parasitol. 201, 59-66. González Canga, A., Sahagún Prieto, A.M., Diez Liébana, M.J., Fernández Martínez, N., Sierra Vega, M., García Vieitez, J.J., 2009. The pharmacokinetics and metabolism of ivermectin in domestic animal species. Vet. J. 179, 25-37.

Gruner, L., Mauléon, H., Hubert, J., Sauvé, C., 1980. A study of ovine gastro-intestinal strongylosis in a sheep flock on permanent pasture. II. Population dynamics of parasites on the pasture in 1977 and an epidemiological interpretation. Ann. Rech. Vet. 11, 133140.

Learmount, J., Gettinby, G., Boughtflower, V., Stephens, N., Hartley, K., Allanson, P., Gutierrez, A.B., Perez, D., Taylor, M., 2015. Evaluation of 'best practice' (SCOPS) guidelines for nematode control on commercial sheep farms in England and Wales. Vet Parasitol. 207, 259-65.

Lespine, A., Sutra, J.F., Dupuy, J., Alvinerie, M., Aumont, G., 2004. The influence of parasitism on the pharmacokinetics of moxidectin in lambs. Parasitol. Res. 93, 121-126. Levecke, B., Dobson, R.J., Spreybroeck, N., Vercruysse, J., Charlier, J., 2012. Novel insights in the faecal egg count reduction test for monitoring drug efficacy against gastrointestinal nematodes of veterinary importance. Vet. Parasitol. 188, 391-396.

Lifschitz, A., Virkel, G. Sallovitz, J. Sutra, J.F., Galtier, P. Alvinerie, M., Lanusse, C., 2000. Comparative distribution of ivermectin and doramectin to parasite location tissues in cattle. Vet. Parasitol. 87, 327-338. 
Lloberas, M., Alvarez, L., Entrocasso, C., Virkel, G., Ballent, M., Mate, L., Lanusse, C., Lifschitz, A., 2013. Comparative tissue pharmacokinetics and efficacy of moxidectin, abamectin and ivermectin in lambs infected with resistant nematodes: Impact of drug treatments on parasite P-glycoprotein expression. Int. J. Parasitol. Drugs Drug Resist. 3, $20-27$.

MAFF (Ministry of Agriculture, Fisheries and Food), 1986. Manual of Veterinary Parasitological Laboratory Techniques, HMSO, London, 160 pp.

Mejía, M.E., Fernández Igartúa, B.M., Schmidt, E.E., Cabaret, J., 2003. Multispecies and multiple anthelmintic resistance on cattle nematodes in a farm in Argentina: the beginning of high resistance? Vet. Res. 34, 461-467.

Paraud, C., Chartier, C., Devos, J., 2013. Cas d'inefficacité de l'éprinomectine pour-on dans un élevage caprin. Bulletin des Groupements Techniques Vétérinaires 70, 97-103.

Presidente, P.J.A., 1985. Methods for detection of resistance to anthelmintics. In: Anderson, N., Waller, P.J. (Eds), Resistance in Nematodes to Anthelmintic Drugs. CSIRO and Australian Wool Corporation Technical Publication, pp. 13-28.

Raynaud, J.P., 1970. Study of the efficiency of a quantitative coproscopic technic for the routine diagnosis and control of parasitic infestations of cattle, sheep, horses and swine. Ann. Parasitol. Hum. Comp. 45, 321-342.

Rose, H., Rinaldi, L., Bosco, A., Mavrot, F., de Waal, T., Skuce, P., Charlier, J., Torgerson, P.R., Hertzberg, H., Hendrickx, G., Vercruysse, J., Morgan, E.R., 2015. Widespread anthelmintic resistance in European farmed ruminants: a systematic review. Vet. Rec. doi: 10.1136/vr.102982.

Van Zeveren, A.M., Casaert, S. Alvinerie, M., Geldhof, P., Claerebout, E., Vercruysse, J., 2007. Experimental selection for ivermectin resistance in Ostertagia ostertagi in cattle. Vet. Parasitol. 150, 104-110. 
Table 1: mean faecal egg counts in the control and treated groups before (J0) and after treatment (J16) with either ivermectin (IVM) or moxidectin (MOX); percentage of reduction estimated by the Presidente formulae in both flocks (IC 95\%) (n=15)

\begin{tabular}{|c|c|c|c|c|c|}
\hline & & & Control group & IVMgroup & MOX group \\
\hline \multirow{5}{*}{ Flock 1} & \multirow[t]{2}{*}{ J0 } & $\begin{array}{c}\text { Number of } \\
\text { positive } \\
\text { animals }\end{array}$ & 14 & 14 & 14 \\
\hline & & $\begin{array}{c}\text { Mean epg } \\
\text { (SD) }\end{array}$ & $350(325)$ & $430(336)$ & 367 (291) \\
\hline & \multirow[t]{2}{*}{$\mathrm{J} 16$} & $\begin{array}{l}\text { Number of } \\
\text { positive } \\
\text { animals }\end{array}$ & 9 & 10 & 9 \\
\hline & & $\begin{array}{l}\text { Mean epg } \\
\text { (SD) }\end{array}$ & $118(128)$ & $250(331)$ & $143(248)$ \\
\hline & $\begin{array}{c}\% \text { of } \\
\text { reduction } \\
{[\mathrm{CI} 95 \%]}\end{array}$ & & - & $-17[-227-58]$ & $13[-152-70]$ \\
\hline \multirow{5}{*}{ Flock 2} & \multirow[t]{2}{*}{ J0 } & $\begin{array}{l}\text { Number of } \\
\text { positive } \\
\text { animals }\end{array}$ & 13 & 15 & \\
\hline & & $\begin{array}{l}\text { Mean epg } \\
\text { (SD) }\end{array}$ & 213 (215) & 380 (189) & 247 (172) \\
\hline & \multirow[t]{2}{*}{$\mathrm{J} 16$} & $\begin{array}{c}\text { Number of } \\
\text { positive } \\
\text { animals }\end{array}$ & 13 & 3 & 0 \\
\hline & & $\begin{array}{l}\text { Mean epg } \\
\text { (SD) }\end{array}$ & 313 (381) & $30(90)$ & $0(0)$ \\
\hline & $\begin{array}{c}\% \text { of } \\
\text { reduction } \\
\text { [CI 95\%] }\end{array}$ & & - & 96 [84-98] & 98 [86-100] \\
\hline
\end{tabular}


Table 2: pharmacokinetic parameters describing the disposition of ivermectin (IVM) and moxidectin (MOX) in plasma after oral administrations $\left(0.2 \mathrm{mg} / \mathrm{kg}\right.$ BW) to sheep. $\mathrm{C}_{\max }$ : observed peak plasma concentration; $\mathrm{T}_{\max }$ : time to reach $\mathrm{C}_{\max }$; $\mathrm{AUC}_{\text {last: }}$ area under the plasma concentration vs time curve; MRT: mean residence time. Values are the mean \pm standard deviation of 6 animals.

\begin{tabular}{ccc}
\hline & IVM & MOX \\
\hline $\mathbf{C}_{\max }(\mathbf{n g} / \mathbf{m L})$ & $16.38 \pm 5.97^{\mathrm{a}}$ & $9.64 \pm 1.87^{\mathrm{b}}$ \\
\hline $\mathbf{T}_{\max }(\mathbf{d})$ & $0.66 \pm 0.26^{\mathrm{a}}$ & $0.5^{\mathrm{a}}$ \\
\hline $\mathbf{A U C}_{\text {last }}$ (ng/ mL.d) & $29.75 \pm 10.47^{\mathrm{a}}$ & $22.16 \pm 3.41^{\mathrm{a}}$ \\
\hline MRT (d) & $1.90 \pm 0.44^{\mathrm{a}}$ & $3.96 \pm 0.42^{\mathrm{b}}$ \\
\hline a, b different superscripts in a row indicate significant differences between IVM and MOX \\
pharmacokinetic parameters (p<0.05).
\end{tabular}


Table 3: mean strongyle numbers in the abomasum, small intestine and caecum of the control, ivermectin (IVM) and moxidectin (MOX) groups ten days after administration of anthelmintics ( $\mathrm{n}=6$ lambs per group) and percentage of reduction in the treated groups compared to the control group

\begin{tabular}{|c|c|c|c|c|}
\hline & Group & $\begin{array}{c}\text { Number of } \\
\text { infested lambs }\end{array}$ & $\begin{array}{c}\text { Mean burden } \\
\text { (min-max) }\end{array}$ & $\begin{array}{c}\text { \% reduction } \\
\text { (CI 95\%) }\end{array}$ \\
\hline \multirow{3}{*}{ Abomasum } & Control & 6 & $578^{a}(220-670)$ & - \\
\hline & IVM & 6 & $57^{b}(10-110)$ & 90.2 [81.5-94.8] \\
\hline & MOX & 6 & $85^{b}(30-200)$ & 85.3 [72.4-92.2] \\
\hline \multirow{3}{*}{$\begin{array}{c}\text { Small } \\
\text { intestine }\end{array}$} & Control & 6 & $1088^{a}(770-1430)$ & - \\
\hline & IVM & 0 & $0^{\mathrm{b}}$ & 100 \\
\hline & MOX & 3 & $8^{b}(0-30)$ & 99.2 [97.5-99.8] \\
\hline \multirow{3}{*}{$\begin{array}{c}\text { Large } \\
\text { intestine }\end{array}$} & Control & 6 & $60^{a}(12-118)$ & - \\
\hline & IVM & 0 & $0^{\mathrm{b}}$ & 100 \\
\hline & MOX & 0 & $0^{\mathrm{b}}$ & 100 \\
\hline \multirow{3}{*}{$\begin{array}{c}\text { Total worm } \\
\text { burden }\end{array}$} & Control & 6 & 1727a (1272-2268) & - \\
\hline & IVM & 6 & $57^{b}(10-110)$ & 94.6 [90.5-96.9] \\
\hline & MOX & 6 & $93^{\mathrm{b}}(40-200)$ & 96.7 [94.2-98.1] \\
\hline
\end{tabular}


Figure 1: concentration time profile of ivermectin (IVM) and moxidectin (MOX) after oral administration $(0.2 \mathrm{mg} / \mathrm{kg} \mathrm{BW})$ to nematode-infected lambs. Mean $\pm \mathrm{SD}(\mathrm{n}=6 \mathrm{lambs}$ per group)

Figure 1

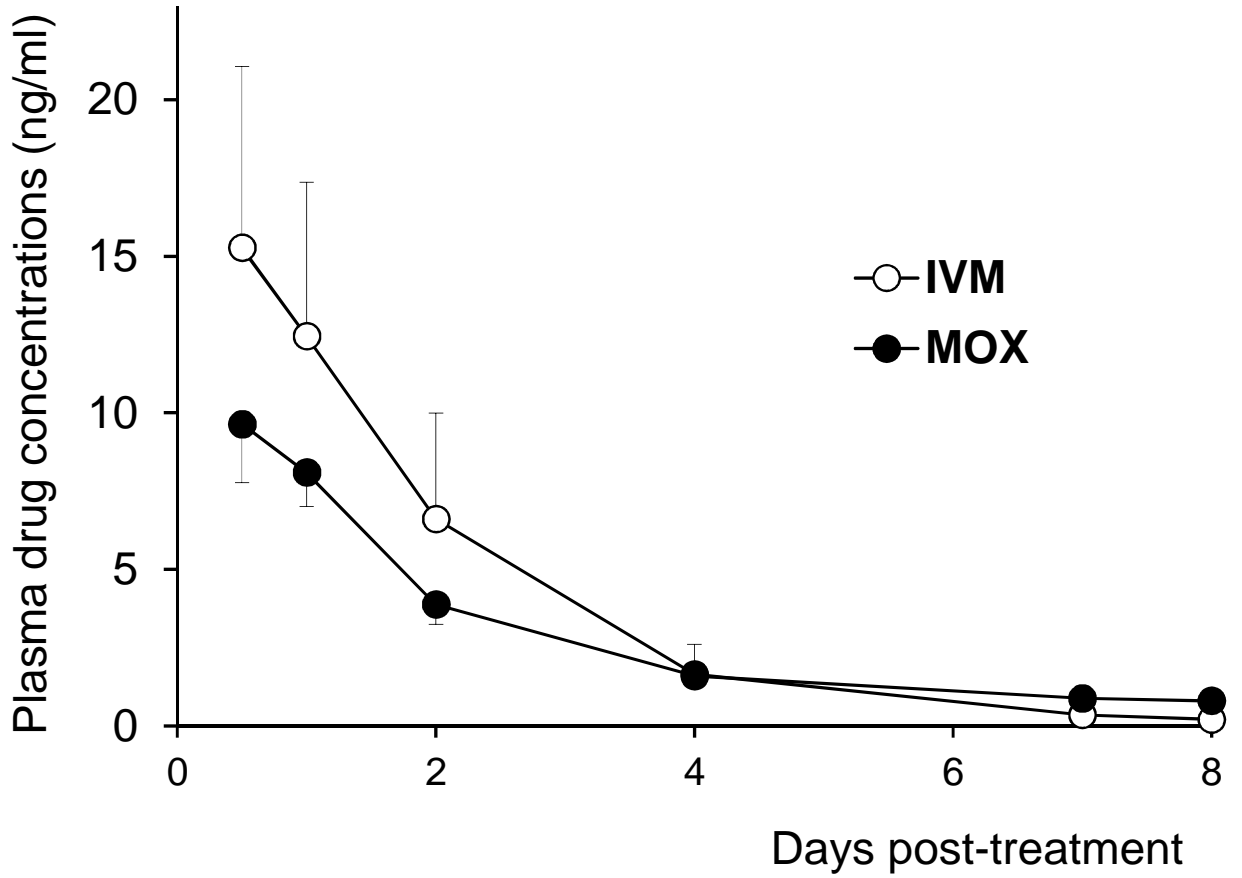


Table 1: mean faecal egg counts in the control and treated groups before (J0) and after treatment (J16) with either ivermectin (IVM) or moxidectin (MOX), percentage of reduction estimated by the Presidente formulae in the 2 flocks (IC 95\%) $(n=15)$

\begin{tabular}{|c|c|c|c|c|c|}
\hline & & & Control group & IVMgroup & MOX group \\
\hline \multirow{5}{*}{ Flock 1} & \multirow[t]{2}{*}{ J0 } & $\begin{array}{c}\text { Number of } \\
\text { positive } \\
\text { animals }\end{array}$ & 14 & 14 & 14 \\
\hline & & $\begin{array}{c}\text { Mean epg } \\
\text { (SD) }\end{array}$ & $350(325)$ & $430(336)$ & 367 (291) \\
\hline & \multirow[t]{2}{*}{$\mathrm{J} 16$} & $\begin{array}{l}\text { Number of } \\
\text { positive } \\
\text { animals }\end{array}$ & 9 & 10 & 9 \\
\hline & & $\begin{array}{l}\text { Mean epg } \\
\text { (SD) }\end{array}$ & $118(128)$ & $250(331)$ & $143(248)$ \\
\hline & $\begin{array}{c}\% \text { of } \\
\text { reduction } \\
{[\mathrm{CI} 95 \%]}\end{array}$ & & - & $-17[-227-58]$ & $13[-152-70]$ \\
\hline \multirow{5}{*}{ Flock 2} & \multirow[t]{2}{*}{ J0 } & $\begin{array}{l}\text { Number of } \\
\text { positive } \\
\text { animals }\end{array}$ & 13 & 15 & \\
\hline & & $\begin{array}{l}\text { Mean epg } \\
\text { (SD) }\end{array}$ & 213 (215) & 380 (189) & 247 (172) \\
\hline & \multirow[t]{2}{*}{$\mathrm{J} 16$} & $\begin{array}{c}\text { Number of } \\
\text { positive } \\
\text { animals }\end{array}$ & 13 & 3 & 0 \\
\hline & & $\begin{array}{l}\text { Mean epg } \\
\text { (SD) }\end{array}$ & 313 (381) & $30(90)$ & $0(0)$ \\
\hline & $\begin{array}{c}\% \text { of } \\
\text { reduction } \\
\text { [CI 95\%] }\end{array}$ & & - & 96 [84-98] & 98 [86-100] \\
\hline
\end{tabular}


Table 2: pharmacokinetic parameters describing the disposition of ivermectin (IVM) and moxidectin (MOX) in plasma after oral administrations $\left(0.2 \mathrm{mg} / \mathrm{kg}\right.$ BW) to sheep. $\mathrm{C}_{\max }$ : observed peak plasma concentration; $\mathrm{T}_{\max }$ : time to reach $\mathrm{C}_{\max }$; $\mathrm{AUC}_{\text {last: }}$ area under the plasma concentration vs time curve; MRT: mean residence time. Values are the mean \pm standard deviation of 6 animals.

\begin{tabular}{ccc}
\hline & IVM & MOX \\
\hline $\mathbf{C}_{\max }(\mathbf{n g} / \mathbf{m L})$ & $16.38 \pm 5.97^{\mathrm{a}}$ & $9.64 \pm 1.87^{\mathrm{b}}$ \\
\hline $\mathbf{T}_{\max }(\mathbf{d})$ & $0.66 \pm 0.26^{\mathrm{a}}$ & $0.5^{\mathrm{a}}$ \\
\hline $\mathbf{A U C}_{\text {last }}$ (ng/ mL.d) & $29.75 \pm 10.47^{\mathrm{a}}$ & $22.16 \pm 3.41^{\mathrm{a}}$ \\
\hline MRT (d) & $1.90 \pm 0.44^{\mathrm{a}}$ & $3.96 \pm 0.42^{\mathrm{b}}$ \\
\hline a, b different superscripts in a row indicate significant differences between IVM and MOX \\
pharmacokinetic parameters (p<0.05).
\end{tabular}


Table 3: mean strongyle numbers in abomasums, small intestine and caecums in the control, ivermectin (IVM) and moxidectin (MOX) groups 10 days after administration of anthelmintics ( $\mathrm{n}=6$ lambs per group) and percentage of reduction in the treated groups compared to the control group

\begin{tabular}{|c|c|c|c|c|}
\hline & Group & $\begin{array}{c}\text { Number of } \\
\text { infested lambs }\end{array}$ & $\begin{array}{c}\text { Mean burden } \\
\text { (min-max) }\end{array}$ & $\begin{array}{c}\text { \% reduction } \\
\text { (CI 95\%) }\end{array}$ \\
\hline \multirow{3}{*}{ Abomasum } & Control & 6 & $578^{a}(220-670)$ & - \\
\hline & IVM & 6 & $57^{b}(10-110)$ & 90.2 [81.5-94.8] \\
\hline & MOX & 6 & $85^{b}(30-200)$ & 85.3 [72.4-92.2] \\
\hline \multirow{3}{*}{$\begin{array}{c}\text { Small } \\
\text { intestine }\end{array}$} & Control & 6 & $1088^{a}(770-1430)$ & - \\
\hline & IVM & 0 & $0^{\mathrm{b}}$ & 100 \\
\hline & MOX & 3 & $8^{b}(0-30)$ & 99.2 [97.5-99.8] \\
\hline \multirow{3}{*}{$\begin{array}{c}\text { Large } \\
\text { intestine }\end{array}$} & Control & 6 & $60^{a}(12-118)$ & - \\
\hline & IVM & 0 & $0^{\mathrm{b}}$ & 100 \\
\hline & MOX & 0 & $0^{\mathrm{b}}$ & 100 \\
\hline \multirow{3}{*}{$\begin{array}{c}\text { Total worm } \\
\text { burden }\end{array}$} & Control & 6 & 1727a (1272-2268) & - \\
\hline & IVM & 6 & $57^{b}(10-110)$ & 94.6 [90.5-96.9] \\
\hline & MOX & 6 & $93^{\mathrm{b}}(40-200)$ & 96.7 [94.2-98.1] \\
\hline
\end{tabular}

